\title{
Effects of supplementation of calcium salts of polyunsaturated fatty acids on serum concentrations of progesterone and insulin of pregnant dairy cows
}

\section{Philipe Moriel', Bruno leda Cappellozza ${ }^{1}$, Luiz Felipe Ferraretto ${ }^{1}$, Augusto Cossolino Aboin ${ }^{1}$, Fernanda Victor Rodrigues Vieira ${ }^{1}$, Ricardo de Oliveira Rodrigues ${ }^{1}$, Reinaldo Fernandes Cooke $^{2}$, José Luiz Moraes Vasconcelos ${ }^{1}$}

\footnotetext{
${ }^{1}$ Departamento de Produção Animal, Faculdade de Medicina Veterinária e Zootecnia, Universidade Estadual Paulista, Botucatu, SP, Brasil.

${ }^{2}$ Eastern Oregon Agricultural Research Center, Oregon State University, Burns, OR, USA.
}

\begin{abstract}
Forty-five non-lactating, pregnant Holstein animals (18 heifers and 27 multiparous cows; BW $=561 \pm 114 \mathrm{~kg}$; $\mathrm{BCS}=2.9 \pm 0.3$; days pregnant $=110 \pm 56 \mathrm{~d}$ ) were stratified by initial BW and BCS, and randomly assigned to receive daily (as-fed basis) $0.50 \mathrm{~kg}$ of ground corn plus $0.22 \mathrm{~kg}$ of kaolin $(\mathrm{CON})$, calcium salts of saturated fatty acids (SFA) or polyunsaturated fatty acids (PF) for $14 \mathrm{~d}$. Blood samples were collected on days 0,7 and 14 , immediately prior to $(0 \mathrm{~h})$ and $3,6,9$ and $12 \mathrm{~h}$ after feeding, to determine the serum concentrations of $\mathrm{P}_{4}$ and insulin. No treatment effects were detected for serum concentrations of $\mathrm{P}_{4}(5.52,6.13$ and $5.63 \pm 0.41 \mathrm{ng} / \mathrm{mL}$ for CON, SFA and PF, respectively). No treatment effects were detected for serum concentrations of insulin $(11.5,10.5$ and $10.1 \pm 1.43 \mu \mathrm{IU} / \mathrm{mL}$ for CON, SFA and PF, respectively). Heifers had greater serum concentrations of $\mathrm{P}_{4}$ than multiparous cows ( $\left.6.35 \mathrm{vs} .5 .16 \pm 0.42 \mathrm{ng} / \mathrm{mL}\right)$, but lower serum concentrations of insulin ( $7.0 \mathrm{vs} .14 .4 \pm 1.49 \mu \mathrm{IU} / \mathrm{mL})$. Feeding $0.22 \mathrm{~kg}$ of calcium salts of polyunsaturated fatty acids is not sufficient to increase the serum concentrations of $\mathrm{P}_{4}$ and insulin of non-lactating, pregnant dairy cows.
\end{abstract}

Key Words: hepatic metabolism, linoleic, linolenic, PUFA

\section{Introduction}

Polyunsaturated fatty acids (PUFA), such as linoleic (LA) and linolenic (LNA) acids have been associated with enhanced reproduction of dairy and beef cows (Staples et al., 1998; Lopes et al., 2009, 2011). The mechanisms by which calcium salts of PUFA may decrease pregnancy loss include: 1) increased circulating progesterone $\left(\mathrm{P}_{4}\right)$ concentrations (Stronge et al., 2005; Demetrio et al., 2007); 2) reduced $\mathrm{PGF}_{2 \alpha}$ synthesis and luteolysis (Williams and Stanko, 2000); and 3) enhanced maternal recognition of pregnancy (Wathes et al., 2007). Linoleic acid is a precursor for the synthesis of arachidonic acid, which may increase mitochondrial uptake of cholesterol (Stocco and Clark, 1996), and thus, increase $\mathrm{P}_{4}$ synthesis (Grummer and Carroll, 1991). Also, PUFA supplementation may decrease the hepatic metabolism of $\mathrm{P}_{4}$ (Hawkins et al., 1995). However, limited information exists regarding the effects of relatively small amounts of PUFA supplementation on circulating concentrations of $\mathrm{P}_{4}$ in dairy cows (Reis et al., 2012). Polyunsaturated fatty acids may be partitioned into different locations (e.g. body tissue, milk, and embryo), depending on the priority of the metabolism (Hess et al., 2008). Thus, it is not known if relatively small amounts of
PUFA may increase the circulating concentrations of $\mathrm{P}_{4}$ by increasing the synthesis of $\mathrm{P}_{4}$ and/or decreasing the hepatic metabolism of $\mathrm{P}_{4}$.

Circulating concentrations of insulin usually reflect energy intake of cattle (Staples et al., 1998). Cows with greater serum concentrations of insulin had greater serum concentrations of $\mathrm{P}_{4}$ compared with cows having lower serum concentrations of insulin (Moriel et al., 2008; Lopes et al., 2009). Williams and Stanko (2000) reported that cows supplemented with PUFA had greater circulating insulin concentrations when compared with nonsupplemented cohorts. The mechanisms by which insulin concentrations may affect $\mathrm{P}_{4}$ concentrations include enhanced synthesis of $\mathrm{P}_{4}$ through steroidogenesis (Butler et al., 2004), and reduced hepatic expression of $\mathrm{P}_{4}$ catabolic enzymes P450 2C and 3A (Lemley et al., 2008; Vieira et al., 2013).

Based on this information, it was hypothesized that supplementation of calcium salts of PUFA would increase serum concentrations of $\mathrm{P}_{4}$ and insulin due to an increased $\mathrm{P}_{4}$ synthesis and/or decreased hepatic metabolism of $\mathrm{P}_{4}$. Thus, the objectives were to evaluate the effects of supplementing relatively small amounts of calcium salts of PUFA on serum concentrations of $\mathrm{P}_{4}$ and insulin of dairy cows. 


\section{Material and Methods}

The study was conducted at a commercial dairy farm (Fazenda Globo), located in Borebi, São Paulo, Brazil. The animals utilized in these experiments were cared for in accordance with acceptable practices as outlined in the Guide for the Care and Use of Agricultural Animals in Agricultural Research and Teaching (FASS, 1999).

This experiment was designed to evaluate the effects of calcium salts of PUFA on serum concentrations of $\mathrm{P}_{4}$ and insulin in non-lactating, pregnant cows. This animal category was selected to avoid the partitioning of supplemented FA into milk, which could decrease the PUFA availability for body metabolism. Furthermore, the laboratory utilized ovariectomized cows inserted with an intravaginal device containing $\mathrm{P}_{4}$ as the model for evaluating $\mathrm{P}_{4}$ metabolism (Moriel et al., 2008; Lopes et al., 2009). However, because the experiment was conducted at a commercial dairy farm, ovariectomized cows were not an option. Thus, pregnant cows at later stages of pregnancy were selected in order to have a constant supply of $\mathrm{P}_{4}$ (e.g. corpus luteum- and placenta-derived $\mathrm{P}_{4}$ ), and hence, have a clearer picture of potential effects of PUFA supplementation on $\mathrm{P}_{4}$ metabolism. Forty-five Holstein animals (18 heifers and 27 multiparous cows; $\mathrm{BW}=561 \pm 114 \mathrm{~kg}$; $\mathrm{BCS}=2.9 \pm 0.3$; days pregnant $=$ $110 \pm 56 \mathrm{~d}$ ) were stratified by initial BW and BCS (Wildman et al., 1982). Cows were randomly assigned to receive individual daily (as-fed basis) supplementation of $0.50 \mathrm{~kg}$ of finely ground corn plus $0.22 \mathrm{~kg}$ of kaolin (a rumen-inert indigestible substance; $\mathrm{CON}$ ), calcium salts of saturated fatty acids (SFA; Megalac ${ }^{\circledR}$; Arm \& Hammer Animal Nutrition, Division of Church \& Dwight Co.; Inc.), or calcium salts of polyunsaturated fatty acids (PF; Megalac- $\mathrm{E}^{\circledR}$; Quimica Geral do Nordeste, Rio de Janeiro, Brazil) (Table 1) for $14 \mathrm{~d}$. The SFA treatment was included as an iso-lipidic, iso-caloric, and iso-nitrogenous control treatment relative to PF. Also, a supplementation period of $14 \mathrm{~d}$ was utilized based on previous findings (Lopes et al., 2009, 2011) observing positive effects of PUFA supplementation on reproductive performance of beef cows. Treatments were top-dressed daily (07.00 hours) and individually. Cows were offered free choice access to a corn silage-based diet (Table 2), in a dry lot facility with free access to Tifton (Cynodon spp) pastures for $14 \mathrm{~d}$. Cows had free access to water throughout the experiment.

Blood samples were collected on days 0, 7 and 14, immediately prior to $(0 \mathrm{~h})$, and $3,6,9$ and $12 \mathrm{~h}$ after the morning supplement feeding, for determination of serum concentrations of $\mathrm{P}_{4}$ and insulin. Blood was collected from the coccygeal vein or artery into commercial blood collection tubes (Vacutainer, $10 \mathrm{~mL}$; Becton Dickinson, Franklin Lakes, NJ), placed on ice immediately and centrifuged at $1500 \times \mathrm{g}$ for $30 \mathrm{~min}$ for serum collection. Harvested serum was stored frozen at $-20^{\circ} \mathrm{C}$ until laboratory analysis.

Serum concentrations of $\mathrm{P}_{4}$ and insulin were determined using a Coat-A-Count Kit (DPC Diagnostic Products Inc.; Los Angeles, CA) solid phase ${ }^{125}$ I RIA, previously validated for cattle (Moriel et al., 2008). The intra- and inter-assay CV were 1.8 and $0.1 \%$ for $\mathrm{P}_{4}$, and 10.3 and $7.4 \%$ for insulin, respectively.

Blood measurements were analyzed as repeated measures using the MIXED procedure of SAS (Statistical Analysis System, version 9.2). The model statement contained the effects of treatment, time, day, parity and the resultant interactions. Cow (treatment $\times$ parity) was included as a random variable and error term for the tests of fixed effects. Cow (treatment $\times$ parity $\times$ day) was included as the subject in the repeated statement. The criterion for

Table 1 - Fatty acid (FA) composition ( $\%$ of total $\left.\mathrm{FA}^{1}\right)$ of calcium salts of FA included in the SFA and PF supplements

\begin{tabular}{lcc}
\hline & \multicolumn{2}{c}{ Treatment } \\
\cline { 2 - 3 } & PF $^{2}$ & SFA $^{3}$ \\
\hline & \multicolumn{2}{c}{ \% of total FA } \\
Lauric acid (12:0) & 0.1 & 0.2 \\
Myristic acid (14:0) & 0.2 & 1.6 \\
Palmitic acid (16:0) & 17.5 & 50.8 \\
Palmitoleic acid (16:1) & 0.3 & 0.0 \\
Stearic acid (18:0) & 5.1 & 4.1 \\
Oleic acid (18:1) & 31.7 & 35.7 \\
Linoleic acid (18:2) & 39.8 & 7.0 \\
Linolenic acid (18:3) & 2.7 & 0.2 \\
Other & 2.6 & 0.4 \\
\hline PF - calcium salts of polyunsaturated fatty acids; SFA - calcium salts of saturated \\
fatty acids. & & \\
${ }^{1}$ Values provided by manufactures. & & \\
2 Megalac-E (Química Geral do Nordeste, Rio de Janeiro, Brazil). \\
${ }^{3}$ Megalac (Arm \& Hammer Animal Nutrition, Division of Church \& Dwight Co.; Inc.).
\end{tabular}

Table 2 - Ingredients and nutritional composition of the base diet fed to cows

\begin{tabular}{|c|c|}
\hline Ingredients & Basal diet (\% of DM) \\
\hline Corn silage & 56.3 \\
\hline Whole cottonseed & 6.90 \\
\hline Corn finely ground & 14.2 \\
\hline Soybean hulls & 4.89 \\
\hline Soybean meal & 9.79 \\
\hline Mineral/vitamin $\operatorname{mix}^{1}$ & 3.00 \\
\hline Panicum maximim cv. Mombasa & 4.88 \\
\hline Total & 100.0 \\
\hline \multicolumn{2}{|l|}{ Nutrient profile ${ }^{2}, \%$ of dry matter } \\
\hline Dry matter & 49.8 \\
\hline Total digestible nutrients & 68.7 \\
\hline Crude protein & 17.0 \\
\hline Calcium & 0.65 \\
\hline Phosphorus & 0.42 \\
\hline
\end{tabular}

R. Bras. Zootec., v.43, n.1, p.20-26, 2014 
choosing the covariance structure was the one with the lowest Akaike information criterion. The autoregressive covariance structure was used for both serum variables. Satterthwaite approximation was used to determine the denominator degrees of freedom for all the tests of fixed effects. Means were separated using PDIFF in all experiments. Significance was set at $\mathrm{P} \leq 0.05$, and tendencies were determined if $\mathrm{P}>0.05$ and $\leq 0.10$.

For comparison of $\mathrm{P}_{4}$ concentrations in cows with insulin above or below the median before feeding, data were analyzed with the UNIVARIATE procedure of SAS for median determination and the MIXED procedure of SAS to determine insulin effects on $\mathrm{P}_{4}$ concentrations. The model statement for this analysis contained the effects of insulin (above or below median), time, and the resultant interaction. For the analysis of insulin concentrations within each group, the model statement included only the effects of time. Period was the random variable and error term for the tests of fixed effect for both analyses within each group. Cow (period) was used as the subject in the repeated statement. Following the same criterion for choosing the covariance structure as mentioned above, the compound symmetry covariance structure was used in all analyses. Satterthwaite approximation was used to determine the denominator degrees of freedom for all the tests of fixed effects. Significance was set at $\mathrm{P} \leq 0.05$, tendencies were determined if $\mathrm{P}>0.05$ and $\mathrm{P} \leq 0.10$. Results are reported according to main effects if no interactions were significant, or according to the highest-order interaction detected.

\section{Results}

Dietary treatments did not affect $(\mathrm{P} \geq 0.52)$ the overall serum concentrations of $\mathrm{P}_{4}$ and insulin (Table 3). Time effects were detected ( $\mathrm{P}<0.01$; Figure 1$)$ for serum concentrations of $\mathrm{P}_{4}$ and insulin. Serum $\mathrm{P}_{4}$ concentrations decreased from $0(6.09 \mathrm{ng} / \mathrm{mL} ; \mathrm{SEM}=0.25)$ to $3 \mathrm{~h}(5.73 \mathrm{ng} / \mathrm{mL}$; SEM $=0.25)$, but remained unaltered from 3 to $12 \mathrm{~h}$ $(5.60 \mathrm{ng} / \mathrm{mL} ; \mathrm{SEM}=0.25)$ after feeding the supplements. Serum concentrations of insulin peaked at $3 \mathrm{~h}(12.51 \mu \mathrm{IU} / \mathrm{mL}$; $\mathrm{SEM}=0.93)$, but decreased $12 \mathrm{~h}$ after supplements were offered $(7.69 \mu \mathrm{IU} / \mathrm{mL}$; SEM $=0.98)$.

A parity effect was detected ( $\mathrm{P}=0.04$; Table 4$)$ for serum $\mathrm{P}_{4}$ concentrations. Heifers had greater serum concentrations of $\mathrm{P}_{4}$ compared with multiparous cows $(6.35$ vs. $5.16 \mathrm{ng} / \mathrm{mL}$, respectively; $\mathrm{SEM}=0.42)$. Similarly, a parity effect $(\mathrm{P}<0.001$; Table 4) was detected on serum concentrations of insulin because multiparous cows had greater $(\mathrm{P}<0.01)$ insulin concentrations $(14.4 \mu \mathrm{IU} / \mathrm{mL} ; \mathrm{SEM}=1.08)$ than heifers $(7.0 \mu \mathrm{IU} / \mathrm{mL} ; \mathrm{SEM}=1.49)$.
For comparison of serum $\mathrm{P}_{4}$ concentrations according to serum insulin concentrations, the results within each group were combined and separated by cows having serum concentrations of insulin above or below the median $(10.41 \mu \mathrm{IU} / \mathrm{mL})$ immediately before the morning feeding. Cows having insulin concentrations above the median had similar $(\mathrm{P}=0.15)$ mean concentrations of $\mathrm{P}_{4}$ compared with cows having insulin concentrations below the median ( 5.64 vs. $5.87 \mathrm{ng} / \mathrm{mL}$, respectively; $\mathrm{SEM}=0.25$; Figure 2). There was a tendency for treatment $\times$ time effect $(\mathrm{P}=0.06)$ on serum concentrations of $\mathrm{P}_{4}$. Cows having

Table 3 - Overall serum concentrations of progesterone and insulin of cows fed rumen-inert PUFA or SFA

\begin{tabular}{lccccc}
\hline \multirow{2}{*}{ Item } & \multicolumn{3}{c}{ Treatment } & \multirow{2}{*}{ SEM } & P-value \\
\cline { 2 - 4 } & CON & SFA & PF & & \\
\hline Progesterone, $\mathrm{ng} / \mathrm{mL}$ & 5.52 & 6.13 & 5.63 & 0.41 & 0.52 \\
Insulin, $\mu \mathrm{IU} / \mathrm{mL}$ & 11.5 & 10.5 & 10.1 & 1.43 & 0.76 \\
\hline
\end{tabular}

CON - Cows fed daily $0.50 \mathrm{~kg}$ of finely ground corn plus $0.22 \mathrm{~kg}$ of a rumen-iner indigestible substance (kaolin); SFA - Cows fed daily $0.50 \mathrm{~kg}$ of finely ground corn plus $0.22 \mathrm{~kg}$ of calcium salts of short-chain fatty acids; PF - Cows fed daily $0.50 \mathrm{~kg}$ of finely ground corn plus $0.22 \mathrm{~kg}$ of calcium salts of polyunsaturated fatty acids. SEM - standard error of the mean.

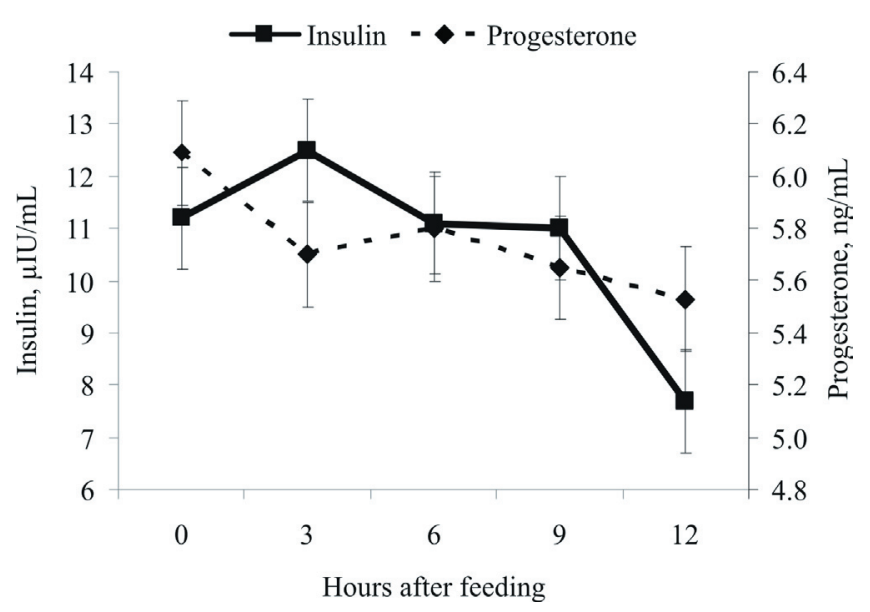

Within each sampling time $(0,3,6,9$ and $12 \mathrm{~h})$, serum concentrations of $\mathrm{P}_{4}$ and insulin were grouped by treatment and day of collection (d 0,7 and 14). Cows were randomly assigned to receive individual supplementation of $0.50 \mathrm{~kg}$ of finely ground corn plus $0.22 \mathrm{~kg}$ kaolin (CON), calcium salts of saturated FA (SFA), or calcium salts of PUFA (PF) for $14 \mathrm{~d}$.

Figure 1 - Serum concentrations of progesterone $\left(\mathrm{P}_{4}\right)$ and insulin of non-lactating, pregnant dairy cows.

Table 4 - Serum concentrations of insulin and progesterone of heifers and multiparous cows

\begin{tabular}{lccrr}
\hline \multirow{2}{*}{ Item } & \multicolumn{2}{c}{ Parity $^{1}$} & SEM $^{2}$ & P-value \\
\cline { 2 - 3 } & Heifers & Cows & & \\
\hline Progesterone, $\mathrm{ng} / \mathrm{mL}$ & 6.35 & 5.16 & 0.42 & 0.04 \\
Insulin, $\mu \mathrm{IU} / \mathrm{mL}$ & 7.0 & 14.4 & 1.49 & $<0.01$ \\
\hline
\end{tabular}

${ }^{1}$ Heifers and cows fed $0.50 \mathrm{~kg}$ of finely ground corn plus $0.22 \mathrm{~kg}$ of kaolin $(\mathrm{CON})$, calcium salts of saturated FA (SFA), or PUFA (PF).

${ }^{2}$ Largest standard error of the mean. 


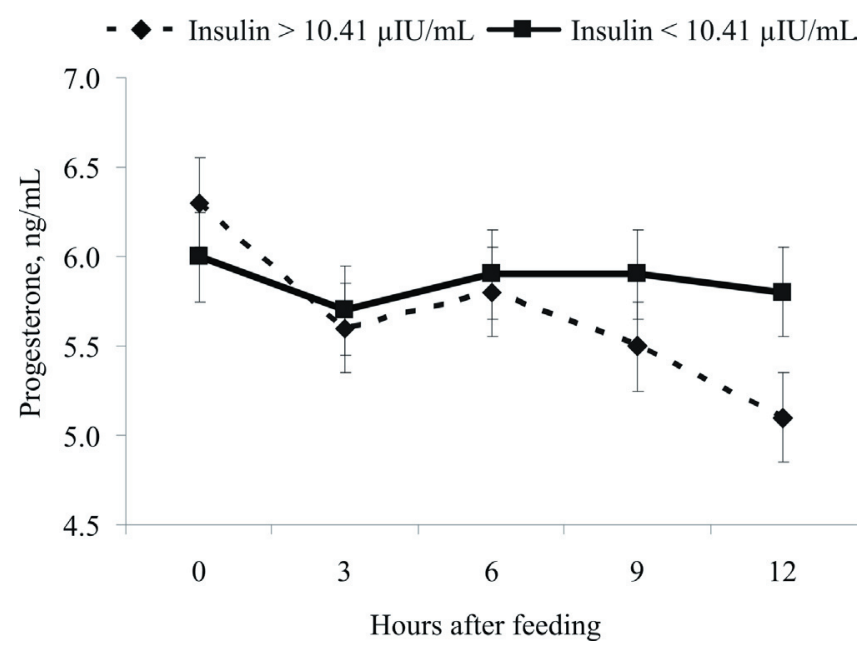

Figure 2 - Serum concentrations of progesterone $\left(\mathrm{P}_{4}\right)$ of nonlactating, pregnant dairy cows having serum concentrations of insulin above or below the median (10.41 $\mu \mathrm{IU} / \mathrm{mL})$ immediately before the morning feeding.

insulin concentrations above the median had lower $(\mathrm{P}<0.01)$ concentrations of $\mathrm{P}_{4} 12 \mathrm{~h}$ after the supplements were offered compared with cows having insulin concentrations below the median (5.14 vs. $5.84 \mathrm{ng} / \mathrm{mL}$, respectively; $\mathrm{SEM}=0.25)$.

\section{Discussion}

Polyunsaturated fatty acids play an important role on stimulation and inhibition of prostaglandin production (Staples et al., 1998), affecting ovary function and follicular development (Thatcher et al., 2004), improving the oocyte quality (Fouladi-Nashta et al., 2007), and increasing the first-service conception rate (Thatcher et al., 2006; Lopes et al., 2009). Although there is evidence that feeding fatty acids improved the energy status of lactating dairy cows (Staples et al., 1998), an enhanced reproductive performance may occur apart from an improved energy status of the animals (Sklan et al., 1991). In agreement, Reis et al. (2012) reported that feeding calcium salts of polyunsaturated fatty acids (PUFA) at $1.1 \%$ of diet DM to lactating dairy cows did not affect DM or energy intake, but decreased pregnancy losses compared with control cows that did not receive PUFA supplementation.

Adding calcium soaps of FA to the diet increased serum concentrations of $\mathrm{P}_{4}$ in bovine females (Hightshoe et al., 1991; Hawkins et al., 1995). Greater concentrations of $\mathrm{P}_{4}$ before and after breeding are associated with enhanced fertility (Folman et al., 1973) and embryonic survival (Mann et al., 2006). However, the present study showed no effects of feeding $0.22 \mathrm{~kg}$ of rumen-inert source of SFA or PUFA on serum concentrations of $\mathrm{P}_{4}$ compared with feeding a non-fat control supplement. There are several potential explanations for the outcomes of this study, including: 1) insufficient amount of PUFA to decrease the hepatic clearance of $\mathrm{P}_{4}$;2) length of supplementation period; and 3) frequency of blood sampling.

Approximately 3 to $4 \mathrm{~h}$ following feeding, there is an increase in the rate of blood flow to the liver. This event leads to an increase in the metabolism of $\mathrm{P}_{4}$ by hepatic cells (Sangsritavong et al., 2002), which results in decreased concentrations of $\mathrm{P}_{4}$ after feeding (Sangsritavong et al., 2002; Vasconcelos et al., 2003). This response was observed in the present study, since all treatments had a decrease in $\mathrm{P}_{4}$ concentrations at approximately 3 to $4 \mathrm{~h}$ following feeding (Figure 1). Hepatic clearance of $\mathrm{P}_{4}$ may be diminished by adding PUFA to the diet. Sangsritavong et al. (2002) reported increased hepatic $\mathrm{P}_{4}$-half life, and decreased clearance of $\mathrm{P}_{4}$ in non-lactating dairy cows infused with an emulsion of soybean oil. Piccinato et al. (2010) reported decreased hepatic clearance of $\mathrm{P}_{4}$ in vitro when concentrations of LNA were 100 to $300 \mu \mathrm{M}$. However, plasma concentrations of $\mathrm{P}_{4}$ did not increase after in vivo infusions of $490 \mathrm{~mL}$ of linseed oil (56\% LNA and $16.4 \%$ LA) in lactating dairy cows. Those authors concluded that the plasma concentrations of LNA (less than $8 \mu \mathrm{M}$ ) after the linseed oil infusions were not sufficient to inhibit the key enzymes responsible for $\mathrm{P}_{4}$ metabolism ( $\mathrm{P} 4502 \mathrm{C}$ and $\mathrm{P} 4503 \mathrm{~A}$ ) and thus, did not decrease hepatic clearance of $\mathrm{P}_{4}$. Hawkins et al. (1995) reported increased serum concentrations of $\mathrm{P}_{4}$ in pregnant heifers when calcium salts of FA were fed at $0.57 \mathrm{~kg} / \mathrm{heifer}$ daily. Fouladi-Nashta et al. (2007) only observed a tendency for greater $\mathrm{P}_{4}$ concentrations when lactating dairy cows were fed $0.80 \mathrm{~kg} / \mathrm{d}$ of calcium salts of FA compared with $0.20 \mathrm{~kg} / \mathrm{d}$. The results of the present study are in agreement with Lopes et al. (2009) and Reis et al. (2012), who did not observe increase in serum $\mathrm{P}_{4}$ concentrations by adding calcium salts of PUFA at approximately $0.20 \mathrm{~kg} / \mathrm{cow}$ daily. Taking these results together, it is possible that adding $0.22 \mathrm{~kg}$ of PF did not result in sufficient amounts of PUFA to decrease the hepatic clearance of $\mathrm{P}_{4}$.

Duration of the supplementation period is another potential reason for the discrepancy between the results of the present study and others (Hightshoe et al., 1991; Hawkins et al., 1995). In the present study, a supplementation period of $14 \mathrm{~d}$ was used based on previous studies from our laboratory (Lopes et al., 2009, 2011). Hawkins et al. (1995) fed calcium salts of FA to pregnant heifers starting $100 \mathrm{~d}$ before parturition through day 12 of the third estrus cycle. Hightshoe et al. (1991) fed calcium salts of FA to multiparous beef cows from parturition throughout the second postpartum ovulation. Therefore, it is possible 
that longer periods of fat supplementation are required to potentially increase circulating concentrations of $\mathrm{P}_{4}$.

In contrast to the results of the present study, Lopes et al. (2009) reported greater concentrations of $\mathrm{P}_{4}$ when ovariectomized cows were fed $0.10 \mathrm{~kg} / \mathrm{d}$ of rumen-inert PUFA (39.8\% LA) compared with feeding a non-fat control supplement, but no effect on $\mathrm{P}_{4}$ concentrations when same rumen-inert PUFA were provided at $0.20 \mathrm{~kg} / \mathrm{d}$. The reason for $0.10 \mathrm{~kg} / \mathrm{d}$ of rumen-inert PUFA resulting in greater concentrations of $\mathrm{P}_{4}$ in the study of Lopes et al. (2009) remains unclear. The less frequent blood sampling in the present study could be one of the reasons for the lack of differences detected in the circulating serum concentrations of $\mathrm{P}_{4}$. Hawkins et al. (1995) collected blood samples at -60 , -30 and 0 min before ovariectomy and 15, 30, 45, 60, 90 and $120 \mathrm{~min}$ after ovariectomy. Thereafter, blood samples were collected hourly for $5 \mathrm{~h}$, and every other hour for an additional 6 h. Lopes et al. (2009) collected blood samples immediately before feeding ( $0 \mathrm{~h})$, and 2, 4, 6, 8, 10 and $12 \mathrm{~h}$ after feeding. A more frequent blood sampling could have increased the chances of detecting treatment effects on circulating concentrations of $\mathrm{P}_{4}$.

Although Piccinato et al. (2010) demonstrated that different concentrations of palmitic (16:0), palmitoleic (16:1), oleic (18:1) and LNA (18:3) inhibited the in vitro metabolism of $\mathrm{P}_{4}$, the concentrations of each FA required to inhibit the hepatic clearance of $\mathrm{P}_{4}$ represents supraphysiological concentrations if utilized in in vivo studies. Therefore, the relative contribution of FA (other than LNA and LA) can be considered inexistent due to the small amount of calcium salts of FA provided in this study $(0.22 \mathrm{~kg} / \mathrm{cow}$ daily).

The effects of fat supplementation on insulin concentrations are varied, showing increase (Blum et al., 1985; Reis et al., 2012), no effect (Fouladi-Nashta et al., 2007; Reis et al., 2012), and decrease in concentrations of insulin after fat supplementation (Relling and Reynolds, 2007). Insulin concentrations reflect energy intake, and therefore, differences in insulin concentrations can be due to differences in energy status (Lucy et al., 1991). In the present study, no effects of rumen-inert PUFA supplementation were detected on serum concentrations of insulin, which suggests that differences in DMI did not occur. Likewise, Lopes et al. (2009) did not observe differences in serum concentrations of insulin in beef cows supplemented with up to $0.20 \mathrm{~kg} / \mathrm{d}$ rumen-inert PUFA. Reis et al. (2012) reported that adding calcium salts of PUFA ( $1.1 \%$ of diet $\mathrm{DM}$ ) increased serum $\mathrm{P}_{4}$ concentrations, and tended to increase serum insulin concentrations in primiparous, but not multiparous cows, which suggests that the outcome of fat supplementation is dependent on the category of animal being used. Thus, it is possible that the lack of differences detected in serum insulin concentrations may be a result of the animal category used in the present study. Further evaluations are required to confirm this hypothesis.

Circulating concentrations of $\mathrm{P}_{4}$ are highly affected by feed intake (Vasconcelos et al., 2003; Cooke et al., 2007; Moriel et al., 2008). The concentration of insulin peaked $3 \mathrm{~h}$ after feeding, whereas those of $\mathrm{P}_{4}$ decreased after feeding (Figure 1). The time effects detected for $\mathrm{P}_{4}$ concentrations were similar to previous reports (Vasconcelos et al., 2003; Cooke et al., 2007; Moriel et al., 2008). In the present study, pregnant heifers had greater serum concentrations of $\mathrm{P}_{4}$ compared with pregnant mature cows. In agreement with these results, heifers had greater serum concentrations of $\mathrm{P}_{4}$ from days 5 to 12 of the estrus cycle compared with lactating cows, despite their lower luteal volume on day 14 of the estrus cycle (Wiltbank et al., 2001). Sangsritavong et al. (2002) reported similar absolute increase in liver blood flow (LBF) of lactating and non-lactating dairy cows. However, as a percentage of basal LBF, non-lactating cows had greater increase in LBF compared with lactating cows, probably due to the lower basal LBF. Although the DMI of non-lactating pregnant heifers and cows estimated by the NRC (2001) are similar (as a percentage of BW; $2.0 \%$ of $\mathrm{BW})$, the absolute amount of feed intake is lower for heifers than non-lactating cows. Thus, it is possible that LBF in nonlactating multiparous cows was greater (as a percentage of basal LBF), which consequently may have increased hepatic clearance of $\mathrm{P}_{4}$ and reduced $\mathrm{P}_{4}$ concentrations compared with heifers. However, further evaluation is required to confirm this hypothesis. In addition, although DMI was not measured in this study, greater DMI of non-lactating cows would also suggest greater energy intake and likely greater insulin concentration.

Previous results from our laboratory have shown that peripheral concentrations of insulin potentially modulates the hepatic metabolism of $\mathrm{P}_{4}$ (Moriel et al., 2008; Lopes et al., 2009; Vieira et al., 2010, 2013). Elevated insulin concentrations reduced hepatic expression of $\mathrm{P}_{4}$ catabolic enzymes P450 2C and P450 3A (Lemley et al., 2008; Vieira et al., 2013), which may further increase circulating concentrations of $\mathrm{P}_{4}$ (Moriel et al., 2008; Lopes et al., 2009; Vieira et al., 2010). Accordingly, Vieira et al. (2013) reported that dairy cows in adequate nutritional status receiving jugular glucose infusion $(3 \mathrm{~h}$ at a rate of $0.5 \mathrm{~g} / \mathrm{kg}$ of BW) had greater circulating insulin concentrations and reduced hepatic mRNA expression of $\mathrm{P}_{4}$ catabolic enzymes CYP2C19 and CYP3A4 compared with cohorts receiving saline infusion. Butler et al. (2003) observed that hepatic 
clearance of $\mathrm{P}_{4}$ is reduced linearly after increasing amounts of insulin infusion. Therefore, it is possible that there is a minimum amount of insulin required to reduce the hepatic clearance of $\mathrm{P}_{4}$. In agreement with this hypothesis, Reis et al. (2012) reported that adding calcium salts of PUFA (1.1\% of diet DM) increased serum $\mathrm{P}_{4}$ concentrations, and tended to increase serum insulin concentrations in primiparous, but not multiparous cows. In the present study, there was a tendency (Figure 2) for lower serum concentrations of $\mathrm{P}_{4}$ in cows having serum insulin concentrations greater than the median. Moriel et al. (2008) also reported that cows with insulin concentrations above the median experienced a more severe decrease in $\mathrm{P}_{4}$ concentrations $5 \mathrm{~h}$ after feeding. Those authors attributed this response to increased rumen fermentation, propionate production, and subsequent glucose synthesis, which likely caused the initial elevated concentrations of insulin concentrations but also enhanced hepatic blood flow after feeding. Thus, the increased metabolism of $\mathrm{P}_{4}$ likely overrides a potential inhibitory effect of insulin on $\mathrm{P}_{4}$ catabolism (Moriel et al., 2008).

\section{Conclusions}

Supplementation of relatively small amounts of calcium salts of PUFA $(0.22 \mathrm{~kg})$ is not sufficient to enhance the serum $\mathrm{P}_{4}$ or insulin concentrations of non-lactating, pregnant dairy cows. However, increasing the serum insulin concentrations seems to augment serum concentrations of $\mathrm{P}_{4}$. Therefore, better understanding of how nutritional management can affect insulin synthesis and the rate of hepatic $\mathrm{P}_{4}$ metabolism may improve reproductive efficiency in dairy herds, but further evaluations are required.

\section{References}

Blum, J. W.; Jans, F.; Moses, W.; Frohli, D.; Zemp, M.; Wanner, M.; Hart, I. C.; Thun, R. and Keller, U. 1985. Twenty four hour pattern of blood hormone and metabolite concentrations in high-yielding dairy cows: effects of feeding low or high amounts of starch, or crystalline fat. Zentralblatt für Veterinärmedizin. Reihe B. A. 32:401-418.

Butler, S. T.; Marr, A. L.; Pelton, S. H.; Radcliff, R. P.; Lucy, M. C. and Butler, W. R. 2003. Insulin restores GH responsiveness during lactation-induced negative energy balance in dairy cattle: Effects on expression of IGF-I and GH receptor 1A. Journal of Endocrinology 176:205-217.

Butler, S. T.; Pelton, S. H. and Butler, W. R. 2004. Insulin increases 17 beta-estradiol production by the dominant follicle of the first postpartum follicle wave in dairy cows. Reproduction 127:537-545.

Cooke, R. F.; Arthington, J. D.; Staples, C. R.; Thatcher, W. W. and Lamb, G. C. 2007. Effects of supplement type on performance, reproductive, and physiological responses of Brahman-crossbred females. Journal of Animal Science 85:2564-2574.

Demetrio, D. G. B.; Santos, R. M.; Demetrio, C. G. B. and Vasconcelos, J. L. M. 2007. Factors affecting conception rates following artificial insemination or embryo transfer in lactating Holstein cows. Journal of Dairy Science 90:5073-5082.

FASS - Federation of Animal Science Societies. 1999. Guide for the care and use of agricultural animals in agricultural research and teaching. 1st rev. ed. Federation of Animal Science Societies, Savoy, IL.

Folman, Y.; Rosenberg, M.; Hen, Z. and Davidson, M. 1973. The relationship between plasma progesterone concentration and conception in postpartum dairy cows maintained on two levels of nutrition. Journal of Reproduction and Fertility 34:267-278.

Fouladi-Nashta, A. A.; Gutierrez, C. G.; Gong, J. G.; Garnsworthy, P. and Webb, R. 2007. Impact of dietary fatty acids on oocyte quality and development in lactating dairy cows. Biology of Reproduction 77:9-17.

Grummer, R. R. and Carroll, D. J. 1991. Effects of dietary fat on metabolic disorders and reproductive performance of dairy cattle. Journal of Animal Science 69:3838-3852.

Hawkins, D. E.; Niswender, K. D.; Oss, G. M.; Moeller, C. L.; Odde, K. G.; Sawyer, H. R. and Niswender, G. D. 1995. An increase in serum lipids increases luteal lipid content and alters the disappearance rate of progesterone in cows. Journal of Animal Science 73:541-545.

Hess, B. W.; Moss, G. E. and Rule, D. C. 2008. Adecade of developments in the area of fat supplementation research with beef cattle and sheep. Journal of Animal Science 86:E188-E204.

Hightshoe, R. B.; Cochran, R. C.; Corah, L. R.; Kiracofe, G. H.; Harmon, D. L. and Perry, R. C. 1991. Effects of calcium soaps of fatty acids on postpartum reproductive function in beef cows. Journal of Animal Science 69:4097-4103.

Lemley, C. O.; Butler, S. T.; Butler, W. R. and Wilson, M. E. 2008. Short communication: insulin alters hepatic progesterone catabolic enzymes cytochrome P450 2C and 3A in dairy cows. Journal of Dairy Science 91:641-645.

Lopes, C. N.; Scarpa, A. B.; Cappellozza, B. I.; Cooke, R. F. and Vasconcelos, J. L. M. 2009. Effects of rumen-protected polyunsaturated fatty acid supplementation on reproductive performance of Bos indicus beef cows. Journal of Animal Science 87:3935-3343.

Lopes, C. N.; Cooke, R. F.; Reis, M. M.; Peres, R. F. G. and Vasconcelos, J. L. M. 2011. Strategic supplementation of Ca salts of polyunsaturated fatty acids to enhance reproductive performance of Bos indicus beef cows. Journal of Animal Science 89:3116-3124.

Lucy, M. C.; Staples, C. R.; Michel, F. M. and Thatcher, W. W. 1991. Energy balance and size and number of ovarian follicles detected by ultrasonography in early postpartum dairy cows. Journal of Dairy Science 74:473-482.

Mann, G. E.; Fray, M. D. and Lamming, G. E. 2006. Effects of time of progesterone supplementation on embryo development and interferon- $\mathrm{T}$ production in the cow. The Veterinary Journal 171:500-503.

Moriel, P.; Scatena, T. S.; Sa Filho, O. G.; Cooke, R. F. and Vasconcelos, J. L. M. 2008. Concentrations of progesterone and insulin in serum of nonlactating dairy cows in response to carbohydrate source and processing. Journal of Dairy Science 91:4616-4621.

NRC - National Research Council. 2001. Nutrient requirements of dairy cattle. 7th rev. ed. National Academy of Science, Washington, DC.

Piccinato, C. A.; Sartori, R.; Sangsritavong, S.; Souza, A. H.; Grummer, R. R.; Luchini, D. and Wiltbank, M. C. 2010. In vitro and in vivo analysis of fatty acid effects on metabolism of $17 \beta$-estradiol and progesterone in dairy cows. Journal of Dairy Science 93:1934-1943.

Relling, A. E. and Reynolds, C. K. 2007. Feeding rumen-inert fats differing in their degree of saturation decreases intake and increases plasma concentrations of gut peptides in lactating dairy cows. Journal of Dairy Science 90:1506-1515.

Reis, M. M.; Cooke, R. F.; Ranches, J. and Vasconcelos, J. L. M. 2012. Effects of calcium salts of polyunsaturated fatty acids on productive and reproductive parameters of lactating Holstein cows. Journal of Dairy Science 95:7039-7050. 
Sangsritavong, S.; Combs, D. K.; Sartori, R.; Wiltbank, M. C. and Armentano, L. E. 2002. High fed intake increases blood flow and metabolism of progesterone and estradiol-17 $\beta$ in dairy cattle. Journal of Dairy Science 85:2831-2842.

Sklan, D.; Moallem, U. and Folman, Y. 1991. Effect of feeding calcium soaps of fatty acids on production and reproductive responses in high producing lactating cows. Journal of Dairy Science 74:510-517.

Staples, C. R.; Burke, J. M. and Thatcher, W. W. 1998. Influence of supplemental fats on reproductive tissues and performance of lactating cows. Journal of Dairy Science 81:856-871.

Stocco, D. M. and Clark, B. J. 1996. Regulation of acute production of steroids in steroidogenic cells. Endocrine Reviews 17:221-244.

Stronge, A. J. H.; Sreenan, J. M.; Diskin, M. G.; Mee, J. F.; Kenny, D. A. and Morris, D. G. 2005. Post-insemination milk progesterone concentration and embryo survival in dairy cows. Theriogenology 64:1212-1224.

Thatcher, W. W.; Bilby, T.; Staples, C. R.; MacLaren, L. and Santos, J. E. P. 2004. Effects of polyunsaturated fatty acids on reproductive processes in dairy cattle. p.1-13. In: Proceedings of the Southwest Nutrition and Management Conference.

Thatcher, W. W.; Bilby, T. R.; Bartolome, J. A.; Silvestre, F.; Staples, C. R. and Santos, J. E. P. 2006. Strategies for improving fertility in the modern dairy cows. Theriogenology 65:30-44.

Vasconcelos, J. L. M.; Sangsritavong, S.; Tsai, S. J. and Wiltbank, M. C. 2003. Acute reduction in serum progesterone concentrations after intake in dairy cows. Theriogenology 60:795-807.
Vieira, F. V. R.; Lopes, C. N.; Cappellozza, B. I.; Scarpa, A. B.; Cooke, R. F. and Vasconcelos, J. L. M. 2010. Effects of intravenous glucose infusion and nutritional balance on serum concentrations of nonesterified fatty acids, glucose, insulin, and progesterone concentrations in nonlactating dairy cows. Journal of Dairy Science 93:3047-3055.

Vieira, F. V. R.; Cooke, R. F.; Aboin, A. C.; Lima, P. and Vasconcelos, J. L. M. 2013. Short communication: Acute but transient increase in serum insulin reduces messenger RNA expression of hepatic enzymes associated with progesterone catabolism in dairy cows. Journal of Dairy Science. 96:1085-1089.

Wathes, D. C.; Robert, D.; Abayasekara, E. and Aitken, R. J. 2007. Polyunsaturated fatty acids in male and female reproduction. Biology of Reproduction 77:190-201.

Wildman, E. E.; Jones, G. M.; Wagner, P. E.; Boman, R. L.; Troutt, H. F. and Lesch, T. N. 1982. A dairy cow body condition scoring system and its relationship to selected production characteristics. Journal of Dairy Science 65:495-501.

Williams, G. L. and Stanko, R. L. 2000. Dietary fats as reproductive nutraceuticals in beef cattle. Journal of Animal Science 77(E. Suppl.):1-12.

Wiltbank, M. C.; Sartori, R.; Sangsritavong, S.; Lopez, H.; Haughian, J. M.; Fricke, P. M. and Gumen, A. 2001. Novel effects of nutrition on reproduction in lactating dairy cows. Journal of Dairy Science 84(Supp 1):32(Abstract). 